\title{
A competência municipal para legislar sobre Direito Minerário e a possibilidade de proibição do exercício da atividade extrativa mineral
}

\author{
The legislative authority of the local sphere of government to establish rules regarding \\ Mining Law and the possibility of the prohibition of mining activities
}

Gabriela Ariane Ribeiro Mendes*

Beatriz Souza Costa**

\section{REFERÊNCIA}

MENDES, Gabriela Ariane Ribeiro; COSTA, Beatriz Souza. A competência municipal para legislar sobre Direito Minerário e a possibilidade de proibição do exercício da atividade extrativa mineral Revista da Faculdade de Direito da UFRGS, Porto Alegre, n. 41, p. 251-277, dez. 2019. DOI: <https://doi.org/10.22456/0104-6594.83851>.

\section{RESUMO}

$\mathrm{O}$ artigo discorre acerca das competências legislativas ambientas com vistas a verificar se o ente municipal estaria ou não dotado de competência legislativa para estabelecer normas afetas ao Direito Minerário, podendo, assim, proibir a prática da referida atividade no âmbito de seu território. Para tanto, analisa não só a evolução do Federalismo brasileiro, como também a importância adquirida por aquele ente na sistemática adotada pela Constituição de 1988. A partir disso, estuda-se como tal relevância impacta diretamente na forma de interpretação do complexo modelo de repartição de competência instituído pelo constituinte pátrio. Por fim, examina-se a transversalidade exercida pelo Direito Ambiental no campo do Direito Minerário, de forma a se examinar a possibilidade ou não de, dentro dos limites de sua competência, o Município legislar a respeito desse último. Com fins de atingir a tais objetivos, utilizou-se da metodologia jurídico-teórica, bem como raciocínio dedutivo e pesquisa doutrinária e jurisprudencial. Ao final, concluiu-se que em razão da interferência direta promovida pelo Direito Ambiental no Direito Minerário, o ente municipal encontra-se incumbido de competência legislativa para estabelecer normas que afetem diretamente o exercício da atividade extrativa mineral, sem, entretanto, inviabilizá-la abstratamente.

\section{PALAVRAS-CHAVE}

Federalismo. Competência legislativa municipal. Direito Minerário. Direito Ambiental.

\begin{abstract}
This article discusses if Brazilian Constitution gave the local sphere of government competence to establish laws regarding mining law, to the point that the practice of mining activities could be completely forbidden by that instance of power. In order to achieve the answer to said problem, it analyses not only the evolution of Federalism in Brazil, but also the importance that the constituent gave to the local sphere of government in the 1988 Constitution. In sequence, it elucidates how that importance directly affects the form chosen by the constituent to allocate legislative competences amongst the different instances of power. Lastly, it examines the existing connection between Mining and Environmental Law, in a way that it could affect the capability of the local instance of power to create laws regarding the exploration of mining resources. So as to find the answer to said problem, it was used the legal and theoretical methodology, deductive reasoning and the research through literature and jurisprudence regarding the theme. Throughout this paper, it was concluded that considering the direct interference promoted by Environmental Law in the Mining Law sphere, the local instance was given the power to establish laws regarding mining activities, as long as it doesn't turn it

\footnotetext{
* Mestranda no programa de Pós-Graduação stricto senso em Direito Ambiental e Sustentabilidade da Escola Superior Dom Helder Câmar

** Doutora e Mestre em Direito Constitucional pela Universidade Federal de Minas Gerais (UFMG). Professora na Pós-graduação em Direito Ambiental e Desenvolvimento Sustentável da Escola Superior Dom Helder Câmara e Pró-reitora de pesquisa na ESDHC.
} 
abstractly unfeasible.

\section{KEYWORDS}

Federalism. Local competence. Mining Law. Environmental Law.

\section{SUMÁRIO}

1. Introdução. 2. A Ação Direta De Inconstitucionalidade 1.0000.15.088096-1/000. 3. A mineração no Brasil. 3.1. O tratamento da Constituição Federal e da Constituição do Estado de Minas Gerais sobre a matéria. 3.2. A mineração no município de Lagoa Santa. 4. Repartição de competências ambientais na Constituição de 1988. 4.1. O modelo federal de estado. 4.2. O Federalismo brasileiro. 4.3. A repartição constitucional de competências ambientais. 5. O papel do Ente Municipal e os limites de sua competência. 6. A competência para legislar sobre Direito Minerário e sua interseção com o Direito Ambiental. 7. Conclusão. Referências. Dados da publicação.

\section{INTRODUÇÃO}

O presente artigo se prestará a analisar se o Município, pessoa jurídica de direito público interno reconhecida pela Constituição da República de 1988 como ente federativo de terceiro grau, dotado de autonomia político-administrativa e hierarquicamente idêntico aos demais, foi incumbido, pelo constituinte originário, de competência para legislar sobre Direito Minerário.

Isso porque ainda hoje existem dúvidas acerca do papel desse ente federativo, bem como da abrangência de sua competência legislativa constitucionalmente estabelecida, visto que para a sua delimitação o constituinte se utilizou de uma expressão aberta e sem limites bem definidos.

Para tanto, tomou-se por base a decisão proferida pelo Egrégio Tribunal de Justiça do Estado de Minas Gerais, que, em controle abstrato de constitucionalidade, julgou inconstitucional uma lei instituída pelo município de Lagoa Santa que proibia o exercício de atividade extrativa mineral em zonas urbanas ou de expansão urbana.

A fim de alcançar a resposta do pretendido, realizou-se um estudo do modelo de federalismo adotado no Brasil pela Constituição vigente, bem como de qual a importância do papel exercido pelo Município nessa organização. Em seguida, examinou-se o modelo de repartição de competências ambientais estabelecido pela Lei Fundamental e o alcance da expressão "interesse local", utilizada pelo legislador para definir o âmbito das competências legislativas em seu território.

Por fim, elucidou-se a conexão existente entre os ramos do Direito Minerário e do Direito Ambiental, de forma a estabelecer uma diferenciação entre a competência privativa da União para legislar sobre minas, jazidas e outros recursos minerais, e a competência municipal para editar normas para a proteção ambiental. 
Para atingir os objetivos, a presente pesquisa utilizou-se da metodologia jurídicoteórica, para, a partir de um raciocínio dedutivo e pesquisa doutrinária e jurisprudencial, alcançar repostas para o problema ora proposto.

Importante ressaltar que não constitui o objetivo do presente artigo analisar a adequação formal do procedimento adotado pelo Tribunal de Justiça do Estado de Minas Gerais na análise da constitucionalidade da norma objeto da referida ação, nem se, na decisão proferida houve ou não usurpação de competência constitucional reservada ao Supremo Tribunal Federal. O estudo limitou-se, portanto, ao objeto material da discussão travada no Tribunal, qual seja, a competência municipal para legislar acerca da atividade extrativa mineral.

\section{A AÇÃO DIRETA DE INCONSTITUCIONALIDADE 1.0000.15.088096-1/000}

A Ação Direta De Inconstitucionalidade $n^{0}$ 1.0000.15.088096-1/000, julgada pelo Egrégio Tribunal de Justiça do Estado de Minas Gerais em 14 de setembro de 2016, sob relatoria do Desembargador Moreira Diniz, foi interposta pelo Prefeito do município de Lagoa Santa, contra a Lei municipal 3.716/2015, que proibia a implantação e execução de projetos de extração de minério em zonas urbanas ou de expansão urbana.

Sustentou o autor que a referida lei padece de vício formal de constitucionalidade, uma vez que trata de matéria de competência privativa da União para legislar sobre exploração de recursos minerais, conforme determina o artigo 22, XII, da Constituição da República, bem como matéria de competência privativa do Poder Executivo de dispor sobre organização do solo. Salientou que a proteção ambiental e o desenvolvimento devem caminhar juntos, tendo a legislação municipal extrapolado normas federais sobre o meio ambiente em detrimento de uma atividade econômica regular. Asseverou, por fim, que a lei, se considerada constitucional, reduz drasticamente a receita do município, criando um ônus insuportável e um prejuízo para toda a coletividade.

Em seu voto, o Desembargador Relator traça uma argumentação no sentido de que em nenhuma hipótese o município estaria autorizado a legislar em matéria de mineração. Ressalta que o texto constitucional estabelece em seu artigo 22, XII, uma competência privativa da União para legislar sobre recursos minerais, posto que estes pertencem exclusivamente ao referido ente federativo. Assim, tratando-se de matérias tipicamente relacionadas à esfera do Direito Minerário, não caberia ao Município legislar sobre a matéria. Aduz, por fim, que a 
competência deste ente se limitaria à fiscalização das atividades conforme determina o artigo 23, XI, do texto constitucional.

Os Desembargadores Alberto Vilas Boas, Wagner Wilson, Sandra Fonseca e Edilson Fernandes chamaram a atenção, em seus respectivos votos, para o fato de que o parâmetro a ser observado para aferição da constitucionalidade de leis municipais em ações de controle de constitucionalidade intentadas perante o Tribunal de Justiça deve ser a Constituição Estadual, e não a Constituição Federal, sob pena de se usurpar a competência do Supremo Tribunal Federal.

Nesse sentido, frisaram que o artigo 249, da Constituição do Estado de Minas Gerais estabelece que a política minerária executada pelo Poder Público deve, observando a legislação federal, presar pelo aproveitamento racional de seus recursos, bem como por sua proteção. Esse dispositivo, associado ao artigo 250, VI, do mesmo diploma constitucional, autorizariam a prática de mineração no território do Estado de Minas Gerais.

Ressaltam que o ente municipal, consoante determina o artigo 30, I e II, da Constituição Federal, possui competência legislativa para dispor sobre assuntos de interesse local, bem como estão autorizados a suplementar as legislações federais e estaduais no que couber. Entretanto, ao proibir a prática de mineração no território municipal, além de extrapolar sua competência legislativa, o Município de Lagoa Santa estaria violando o princípio da livre iniciativa previsto nos artigos $1^{\circ}$ e 170 do texto constitucional brasileiro.

Por meio deste trabalho analisa-se, tomando por base a referida decisão proferida pelo Tribunal de Justiça do Estado de Minas Gerais, a competência legislativa do ente municipal para estabelecer normas acerca do Direito Minerário, considerando suas atribuições dentro do pacto federativo.

\section{A MINERAÇÃO NO BRASIL}

A mineração é uma das atividades mais antigas praticadas pela humanidade, sendo de suma importância para a economia brasileira desde a época colonial. A fim de demonstrar de forma mais enfática tal relevância, Enríquez (2007, p. 25) chama atenção para o fato de que a história das civilizações adota diferentes modalidades de minerais como forma de demarcação de seus principais períodos históricos.

A maior parte dos objetos utilizados na vida contemporânea, “ [...] desde as casas dentro das quais os seres humanos abrigam-se e protegem-se contra as intempéries da 
coletividade e a rudeza do meio ambiente, à grande parte dos utensílios necessários à mantença dos hábitos do dia a dia, ao cultivo realizado na agricultura [...]", engloba minerais e seus compostos, não sendo possível conceber a manutenção do estilo de vida atualmente adotado sem a utilização da atividade mineradora (REMÉDIO JÚNIOR, 2013, p. 1).

Em razão da localização e extensão do território brasileiro, existem, espalhados pelo território nacional, uma grande diversidade de minérios, sendo que sua descoberta e exploração foram essenciais para o desenvolvimento industrial do país. Segundo dados do Departamento Nacional de Produção Mineral (DNPM, 2016), em 2011, o Brasil produzia setenta e dois tipos de substâncias minerais, sendo 23 metálicas, 45 não-metálicas e 4 energéticas.

De acordo com uma pesquisa divulgada pelo Instituto Brasileiro de Mineração (IBRAM, 2015), em 2013, a indústria extrativa mineral (com petróleo e gás natural) representou $4,1 \%$ do Produto Interno Bruto nacional (PIB).

Em 2015, consoante dados fornecidos pelo DNPM (2016), existiam cadastros de títulos ativos de pesquisa e lavra para 37 substâncias metálicas, que representavam $76 \%$ do valor total da produção mineral comercializada brasileira. Acerca dessa importância, dissertam Cabral Júnior, Obata, Sintoni e Suslick (2008):

\begin{abstract}
A magnitude da dotação mineral brasileira é traduzida na produção de mais de uma centena de substâncias minerais. Condicionantes como a extensão territorial de dimensões continentais (8,5 milhões de $\left.\mathrm{km}^{2}\right)$ e a expressiva geodiversidade, caracterizada por uma ampla variedade de ambientes geológicos propícios a uma gama de mineralizações, conferem ao Brasil grande potencial mineral, equiparandoo às grandes potências minerais, como EUA, Rússia, Canadá, Austrália e África do Sul. [...]. (CABRAL JÚNIOR et al., 2008, p. 174).
\end{abstract}

Das oito substâncias metálicas mais relevantes para a economia nacional, quais sejam, alumínio, cobre, estanho, ferro, manganês, nióbio, níquel e ouro ${ }^{1}$, Minas Gerais produz sete delas, sendo, ainda, o estado responsável pela maior parcela da produção de ouro e minério de ferro do país (DNPM, 2016). Estima-se que a Indústria de Extração Mineral mineira (sem petróleo e gás natural) provoca, direta e indiretamente, impactos de 1,31\% no total do PIB brasileiro (IBRAM, 2015).

\footnotetext{
${ }^{1}$ Ainda de acordo com o estudo, essas oito substâncias correspondem a 98,5\% do valor de toda a produção comercializada. Para mais informações: <http://www.dnpm.gov.br/dnpm/publicacoes/serie-estatisticas-eeconomia-mineral/anuario-mineral/anuario-mineral-brasileiro/anuario-mineral-brasileiro-2016-metalicos $>$. Acesso em: 22 de abril de 2018.
} 
Apesar de todos esses impactos positivos que são gerados não só na economia, mas também no campo social com investimentos em educação, infraestrutura e geração de empregos, a atividade minerária ainda é uma atividade de grande impacto ambiental. E é justamente em razão desses que se faz necessária a sua regulamentação.

\title{
3.1 O TRATAMENTO DA CONSTITUIÇÃO FEDERAL E DA CONSTITUIÇÃO DO ESTADO DE MINAS GERAIS SOBRE A MATÉRIA
}

Quando se analisa o tratamento constitucional das matérias causadoras de significativo impacto ambiental percebe-se que o constituinte optou por dar especial atenção à mineração, que é mencionada em diversas passagens (Arts. 20, IX; 22, XII; 23, XI; 49, XVI; 174; 176; 177, V; 231, da CR/88, bem como 43 e 44, da ADCT).

Tal desvelo para com a atividade, cujo destaque para a economia nacional restou demonstrado, também se revela quando do exame do próprio artigo 225 da Lei Fundamental, referência central da proteção ambiental brasileira, que, em seu $\S 2^{\circ}$ impõe um ônus específico de reparação da área degrada pelo sujeito explorador.

Em âmbito constitucional, o núcleo regulamentador das atividades que envolvem o uso e exploração do bem mineral se encontra no artigo 176, o qual prevê:

\begin{abstract}
Art. 176. As jazidas, em lavra ou não, e demais recursos minerais e os potenciais de energia hidráulica constituem propriedade distinta da do solo, para efeito de exploração ou aproveitamento, e pertencem à União, garantida ao concessionário a propriedade do produto da lavra. $\S 1^{\circ}$ A pesquisa e a lavra de recursos minerais e o aproveitamento dos potenciais a que se refere o "caput" deste artigo somente poderão ser efetuados mediante autorização ou concessão da União, no interesse nacional, por brasileiros ou empresa constituída sob as leis brasileiras e que tenha sua sede e administração no País, na forma da lei, que estabelecerá as condições específicas quando essas atividades se desenvolverem em faixa de fronteira ou terras indígenas. $\S 2^{\circ}$ É assegurada participação ao proprietário do solo nos resultados da lavra, na forma e no valor que dispuser a lei. $\S 3^{\circ} \mathrm{A}$ autorização de pesquisa será sempre por prazo determinado, e as autorizações e concessões previstas neste artigo não poderão ser cedidas ou transferidas, total ou parcialmente, sem prévia anuência do poder concedente. $\S 4^{\circ}$ Não dependerá de autorização ou concessão o aproveitamento do potencial de energia renovável de capacidade reduzida. (BRASIL, 1988).
\end{abstract}

Conforme se retira do caput do supracitado dispositivo, os bens minerais são de propriedade da União. Tal também é a previsão contida no artigo 20, IX, da Constituição da 
República $^{2}$. Ademais, a propriedade dos bens minerais está dissociada da propriedade do solo, que pode pertencer a um particular.

Apesar da titularidade conferida à União, por força da determinação contida no artigo 173, do texto constitucional, a exploração não é realizada por ela, mas sim cedida mediante concessão ou autorização a um particular, que pode ser tanto uma pessoa física, quanto jurídica. Isso porque, o dispositivo dispõe que a exploração direta da atividade econômica por parte do Estado é excepcional, sendo sua função precípua regular e fiscalizar a atividade exercida pelo particular. Daí denota-se a peculiaridade da modalidade dominial desses recursos, questionada por Hildebrando Herrmann (apud ATAÍDE, 2017, p. 90-91).

Nesse sentido, esse autor assevera que a Constituição atribui o domínio dos recursos minerais à União, e do produto da lavra ao concessionário, sem, contudo, garantir a eles os poderes inerentes à propriedade previstos pela legislação civil ${ }^{3}$. Questiona qual seria, portanto, a utilidade e o alcance desse direito, concluindo que "[...] parece, à semelhança do que ocorre no direito argentino, que trata, apenas de domínio original ou eminente sobre jazida mineral concedida, jamais como domínio útil, a não ser no caso de substâncias monopolizadas e existentes em áreas de reservas nacionais" (HERRMANN apud ATAÍDE, 2017, p. 90-91).

Ataíde (2017, p. 91) discorda de Herrmann em alguns pontos. Frisa que o modelo de propriedade dos bens minerais não representa somente um domínio eminente, que, como expressão da soberania nacional, pode submeter à sua vontade todas as coisas de seu território; mas que, como já concluiu a doutrina administrativa, o modo de exercer o direito de propriedade por parte do Estado é aplicável de forma diversa a quando este instituto recai sobre o particular. Assim, o domínio eminente exercido pelo Estado nas atividades minerárias recai não sobre a anuência da União para que o particular explore o bem mineral, mas sobre a regulação por ele realizada quando do exercício de suas competências legislativa e administrativa.

A Constituição do Estado de Minas Gerais, por sua vez, também trata da exploração mineral. Neste sentido, reproduz em seu artigo 11, XI, a previsão contida no artigo 23, XI, da Constituição da República de 1988, que estabelece, conforme será estudado, competências administrativas comuns. Trata, ainda, da política hídrica e minerária aplicada ao território estadual nos artigos 249 a 255 de seu texto.

\footnotetext{
${ }^{2}$ Art. 20. São bens da União: [...] IX - os recursos minerais, inclusive os do subsolo; [...]. (BRASIL, 1988).

${ }^{3}$ Art. 1.228. O proprietário tem a faculdade de usar, gozar e dispor da coisa, e o direito de reavê-la do poder de quem quer que injustamente a possua ou detenha. [...] (BRASIL, 2002).
} 
Da leitura dos artigos mais relevantes para a questão ora analisada, quais sejam, 249, 250, VI e VII e 251, da $\mathrm{CEMG}^{4}$, tem-se que a Constituição do Estado de Minas Gerais considera que a política de exploração mineral deve presar por seu aproveitamento racional, bem como não pode comprometer o patrimônio natural. Logo, em consonância com a sistemática adotada pela Constituição Federal, ela visa compatibilizar o exercício da atividade mineradora com a proteção ambiental.

No tópico seguinte, será estudado o contexto da mineração em Lagoa Santa, para, mais adiante, verificar se, diante das peculiaridades da economia e da prática de atividade extrativa mineral no âmbito daquela localidade, estaria ou não o Município extrapolando a sua competência legislativa ao proibir a prática da atividade.

\subsection{A MINERAÇÃO NO MUNICÍPIO DE LAGOA SANTA}

Conforme já descrito, o Estado de Minas Gerais é extremamente rico em minério, sendo que a atividade extrativa mineral em seu território é de relevância extrema para a economia brasileira. Por consequência, muitos de seus municípios possuem como atividade econômica de maior relevância a mineração. Em Lagoa Santa não é diferente.

Esse município, que contava em 2007 com uma população equivalente a 44.922 (quarenta e quatro mil novecentos e vinte e dois) habitantes, segundo dados do Instituto Brasileiro de Geografia e Estatística (2010) divulgados no sítio eletrônico da Prefeitura do município, pertence à região metropolitana de Belo Horizonte e possui uma ampla atividade extrativa de calcário, de suma relevância para a economia local.

Ademais, em razão de suas riquezas históricas e culturais, bem como de seu expressivo conjunto de sítios arqueológicos, a União, por meio do Decreto $\mathrm{n}^{\circ}$ 98.881/90, instituiu uma área de proteção ambiental (APA), denominada Carste de Lagoa Santa, cujo objetivo é justamente promover uma compatibilização da proteção dos bens ambientais

\footnotetext{
${ }^{4}$ Art. 249 - A política hídrica e minerária executada pelo Poder Público se destina ao aproveitamento racional, em seus múltiplos usos, e à proteção dos recursos hídricos e minerais, observada a legislação federal. Art. 250 - Para assegurar a efetividade do objetivo do artigo anterior, o Poder Público, por meio de sistema estadual de gerenciamento de recursos hídricos e sistema estadual de gerenciamento de recursos minerários, observará, entre outros, os seguintes preceitos: [...]VI - fomento à pesquisa, à exploração racional e ao beneficiamento dos recursos minerais do subsolo, por meio das iniciativas pública e privada; VII - adoção de instrumentos de controle dos direitos de pesquisa e de exploração dos recursos minerais e energéticos; VIII adoção de mapeamento geológico básico, como suporte para o gerenciamento e a classificação de recursos minerais; $[\ldots]$

Art. 251 - A exploração de recursos hídricos e minerais do Estado não poderá comprometer os patrimônios natural e cultural, sob pena de responsabilidade, na forma da lei. (MINAS GERAIS, 1989).
} 
naturais e histórico-culturais da região com o desenvolvimento econômico, o que envolve também a atividade extrativa mineral. Sobre a região, disserta Fleischer (2006):

O município de Lagoa Santa faz parte da APA - Carste de Lagoa Santa, que foi criada em 1990. Sua criação teve o intuito de preservar o grande acervo arqueológico, geológico, espeleológico, paleontológico, biótico e cultural. A APA é amparada por um complexo código de Zoneamento Ambiental, que rege normas de usos do solo, planos de manejo dos recursos naturais, expansão urbana, regras para construção e reforma, além de controle da atividade industrial, que é representada pelas minas de calcário e fábricas de cimento. A APA está localizada em uma zona de transição entre os ecossistemas da zona da mata, cerrado e sertão, com rica biodiversidade. [...] Todos os sítios arqueológicos estão dispostos próximo da superfície em áreas de pastagens, agricultura ou mineração, ficando muito vulneráveis à degradação ou saque. A atividade de mineração apresenta o maior risco para este patrimônio. As mineradoras exploram a calcita e o calcário, muito abundantes na região, desmatam hectares de mata nativa e alteram a dinâmica da natureza destruindo o habitat natural de diferentes espécies da fauna e flora. [...] (FLEISCHER, 2006, sp.).

Percebe-se, pois, a importância da presente pesquisa no âmbito desse município, uma vez que nele, bem como em tantos outros de conjuntura similar, faz-se necessária a compatibilização da exploração mineral com a proteção ambiental, sendo, portanto, imprescindível a delimitação da esfera de atuação do ente municipal no que tange à matéria.

\section{REPARTIÇÃO DE COMPETÊNCIAS AMBIENTAIS NA CONSTITUIÇÃO DE 1988}

Tem-se que, o exercício do domínio eminente desempenhado pelo Estado sobre o bem mineral se materializa por meio da regulação por ele exercida relativamente à atividade extrativa promovida pelo particular. É o que preleciona o caput do artigo 174, da Constituição da República de 1988, ao prever que "como agente normativo e regulador da atividade econômica, o Estado exercerá, na forma da lei, as funções de fiscalização, incentivo e planejamento [...]" (BRASIL, 1988).

A fim de organizar, bem como tornar mais eficiente o exercício dessas funções, o constituinte pátrio realizou uma repartição de competências, delimitando as atribuições de cada ente federado (União, Estado, Município e Distrito Federal) em diversas matérias, dentre elas o meio ambiente e seus elementos.

O modelo de repartição de competências assumido pelos Estados encontra-se intrinsecamente relacionado à forma de sua organização, que, no Brasil, se dá por via do Federalismo. 


\subsection{O modelo federal de Estado}

O Estado Federal é uma das três formas de organização do Estado identificadas pela teoria clássica, quais sejam, Confederação, Federação e Estado Unitário. Ele consiste em uma união de entes políticos autônomos, dotados de personalidade jurídica de direito público, e é marcado por uma descentralização político-administrativa que se materializa por meio da repartição de competências entre as suas unidades.

Moraes (2009, p. 17) frisa que uma das características que marcam a conformação do Estado Federal, dotando-os de autonomia, é justamente a repartição de competências entre entes distintos ser realizada por via do texto constitucional. Isso porque, caso as atribuições sejam conferidas por lei infraconstitucional, elas podem ser retiradas a qualquer momento pelo ente central.

Esse modelo de Estado, encontra suas origens na Constituição Americana de 1787, que somente atingiu tal forma de organização em razão de toda a conjuntura histórica e social vivenciada na época da independência americana, bem como nos anos que a seguiram.

As Treze Colônias conseguiram sua independência em 1776 e, inicialmente, se organizaram por via de um Estado Confederado, regido por um documento denominado "Artigos da Confederação".

Por meio dele, os Estados, independentes e soberanos, formaram uma aliança política e militar. Essa aliança não possuía poderes executivo e judiciário, sendo dotada de um órgão singular de representação, denominado Congresso Continental, que tinha como único objetivo dirigir o esforço comum de guerra (FARIAS, 1999, p. 42).

Dessa forma, verifica-se que essa Confederação era uma união de Estados dotados de soberania, constituída com a finalidade de mostrar-se como uma unidade forte no plano internacional. Nessa mesma linha, Paulo de Bessa Antunes (2015) afirma que a Confederação era, na prática, um "mero sistema de coordenação diplomática da ação soberana dos estados independentes" (ANTUNES, 2015, p. 5).

A medida que esse modelo começou a apresentar falhas, os Estados Confederados decidiram revisar todo o conteúdo dos Artigos da Confederação, convocando, para tal, a Conferência da Filadélfia de 1787. Dessa conferência surgiu a atual constituição americana, por meio da qual cada estado cedeu sua soberania em favor de um ente central (movimento 
centrípeto), estabelecendo um modelo de Estado Federal, dando início ao Federalismo em sua concepção clássica.

No Brasil, o Estado Federal foi constituído de forma inversa. Ao invés de cada ente periférico voluntariamente ceder sua soberania em favor de um ente central, foi o ente central que, por meio de um ato normativo, descentralizou seu poder, concedendo maior autonomia a eles (movimento centrífugo).

Farias (1999, p. 99-100) ressalta que os movimentos pré-republicanos de 1870 já demonstravam sua preferência pela adoção de um modelo Federativo no Brasil. Citando Pontes de Miranda, assevera que a topografia do território, as zonas diversas em que ele se divide, o clima variado e as diferentes produções apontavam a imprescindibilidade de se instituir uma governança que acompanhasse e respeitasse as divisões criadas pela própria natureza física e impostas pela imensa superfície do território.

Nesse contexto, a Federação surge no Brasil com a promulgação do Decreto $n^{\circ} 1$, de 15 de novembro de 1889, concomitantemente com a Proclamação da República. Assim, observa-se que diferentemente do que se verificou nos EUA, o federalismo brasileiro surge por meio de um simples ato legislativo que transformou as províncias imperiais (Estado Unitário) em Estado-membros (Estado Federal) (FARIAS, 1999, p. 101).

Por meio do artigo $2^{\circ}$ do supracitado decreto, as antigas províncias do regime imperial foram declaradas estados, nos seguintes termos: “As Províncias do Brasil, reunidas pelo laço da Federação, ficam constituindo os Estados Unidos do Brasil” (BRASIL, 1889).

A Constituição de 1891 veio, posteriormente, em seu artigo primeiro, consolidar a criação dos estados-membros: "A Nação brasileira adota como forma de Governo, sob o regime representativo, a República Federativa, proclamada a 15 de novembro de 1889, e constitui-se, por união perpétua e indissolúvel das suas antigas Províncias, em Estados Unidos do Brasil” (BRASIL, 1891).

Nas constituições que a seguiram manteve-se a organização do estado na forma federativa, entretanto alterou-se, de acordo com o momento histórico, o modelo de repartição das competências adotado. Assim, verifica-se que nas constituições promulgadas entre $1891 \mathrm{e}$ 1967/1969 houveram períodos de maior e menor centralização do poder, mantendo-se, entretanto, sua subdivisão entre duas esferas (União e Estados). 
A Constituição de 1988 conferiu uma nova configuração à federação brasileira, prevendo expressamente em seus artigos $1^{05}$ e $18^{6}$ a adoção de um modelo federativo que compreende três esferas de poder, subdividas entre União, Estados, Distrito Federal e Municípios, tidos como entes políticos-administrativos autônomos.

Destarte, garantiu-se aos municípios as mesmas autonomias atribuídas à União e aos Estados, elencando-os, pela primeira vez, dentre os entes federativos. Trouxe, portanto, três esferas de competência: a central (União), a regional (Estados) e local (Municípios). Há, também, dentre os entes federados, o Distrito Federal, que acumula, no âmbito de seu território, as competências atribuídas aos Estados (regional) e aos Municípios (local).

\subsection{O Federalismo Brasileiro}

Consoante leciona Ferreira (2018, p. 29-30), diversos países do mundo adotam a forma federativa de Estado, adaptando-a às peculiaridades de cada local, de maneira que não existe um modelo estanque e absoluto. Em razão disso, a doutrina, a fim de facilitar a compreensão dos modelos existentes, criou classificações, enquadrando-os em categorias como o movimento que levou ao seu surgimento, a forma de repartição das competências, intensidade da concentração do poder nas mãos do ente central, dentre outras que não compõem o objeto do presente artigo.

Quando estudadas, percebe-se que o contexto de seu surgimento influencia diretamente na maneira que o constituinte reparte competências e determina a concentração ou desconcentração do poder.

Conforme já descrito, o Estado Federal brasileiro surgiu por movimento centrífugo, também chamado de federalismo por segregação, uma vez que o poder se encontrava concentrado no ente central que, por via de decreto, descentralizou-o em favor de seus recém estabelecidos entes periféricos.

Apesar de esse movimento de formação indicar uma tendência à centralização dos poderes nas mãos do ente central, o constituinte originário, ao fixar as competências constitucionais, distribuindo-as entre os entes federativos, optou por adotar um federalismo de cooperação ou de equilíbrio, que estabelece áreas de atuação comuns e concorrentes entre as

\footnotetext{
${ }^{5}$ Art. $1^{\circ}$ A República Federativa do Brasil, formada pela união indissolúvel dos Estados e Municípios e do Distrito Federal, constitui-se em Estado Democrático de Direito [...]. (BRASIL, 1988).

6 Art. 18. A organização político-administrativa da República Federativa do Brasil compreende a União, os Estados, o Distrito Federal e os Municípios, todos autônomos, nos termos desta Constituição. (BRASIL, 1988).
} 
suas entidades, visando a execução das atribuições do Estado Brasileiro de forma mais eficiente. Esse modelo adotado impõe o estabelecimento de um diálogo entre as realidades central e local de poder, de forma a melhor atender as demandas sociais por meio da atuação conjunta dos entes federativos (FABRIZ, 2010, p. 84).

Magalhães (2011) leciona que o federalismo brasileiro é absolutamente inovador, uma vez que estabelece três diferentes esferas de poder. Nesse sentido, afirma que com a promulgação da Constituição de 1988 “'...] os municípios brasileiros não só mantém sua autonomia, como conquistam a posição de ente federado, podendo, portanto, elaborar suas Constituições municipais [...], auto-organizando os seus poderes executivos e Legislativo estadual ou federal para a respectiva aprovação" (MAGALHÃES, 2011 apud FERREIRA, 2018, p. 33).

Destarte, ao inovar na instituição de uma esfera local de poder, a intenção do contido no texto constitucional foi justamente valorizar sua autonomia, característica que se reflete diretamente na repartição de competência, conforme analisado no tópico seguinte.

\subsection{A repartição constitucional de competências ambientais}

Consoante o ensinado por José Afonso da Silva (2005, p. 479), competências são "as diversas modalidades de poder de que se servem os órgãos ou entidades estatais para realizar suas funções".

O constituinte adotou como diretriz básica para a sua repartição o princípio da predominância do interesse, de forma que as matérias de interesse nacional ficam a cargo da União, de interesse regional a cargo dos Estados e local dos Municípios, sendo que o Distrito Federal reúne em seu âmbito de atribuições, competências regionais e locais.

Muitas vezes, entretanto, não é possível identificar qual o interesse preponderante no caso, de forma que se criaram técnicas de repartição de competências a fim de evitar a ocorrência de conflitos, sendo elas denominadas horizontal e vertical.

$\mathrm{Na}$ horizontal, a constituição identifica quais são as competências específicas de cada ente, de forma que não há subordinação ou hierarquização entre eles.

Na técnica verticalizada, por sua vez, existem matérias comuns no âmbito de atuação de cada ente federado, podendo mais de um deles legislar acerca de um mesmo assunto. Assim, assume uma característica marcante, qual seja, o estabelecimento de uma relação de subordinação entre o tipo de atuação de cada um. 
A Constituição de 1988, visando assegurar o modelo federativo cooperativo e de equilíbrio adotado, combinou ambas as técnicas de distribuição de competência, de forma que estabelece competências privativas, exclusivas, comuns, concorrentes, supletivas e complementares. Nesse sentido, leciona Silva (2005):

\begin{abstract}
A nossa Constituição adota esse sistema complexo que busca realizar o equilíbrio federativo, por meio de uma repartição de competências que se fundamenta na técnica da enumeração dos poderes da União (arts. 21 e 22), com poderes remanescentes para os Estados (art. $25, \S 1^{\circ}$ ) e poderes definidos indicativamente para os Municípios (art. 30), mas combina com essas reservas de campos específicos (nem sempre exclusivos, mas apenas privativos), possibilidades de delegação (art. 22, §único), áreas comuns em que se preveem atuações paralelas da União, Estados, Distrito Federal e Municípios (art. 23) e setores concorrentes entre a União e Estados em que a competência para estabelecer políticas gerais, diretrizes gerais ou normas gerais cabe à União, enquanto se defere aos Estados e até aos Municípios a competência suplementar. (SILVA, 2005, p. 479).
\end{abstract}

O artigo 225, da Constituição da República de $1988^{7}$, núcleo jurídico da proteção ambiental no Brasil, elenca em seu caput o meio ambiente ecologicamente equilibrado como direito fundamental, de forma que Costa (2016) frisa que o simples fato de o tema "proteção ambiental" não se encontrar no título "Dos Direitos e Garantias Fundamentais" não é capaz de descaracterizá-lo como tal. Ademais, determina que essa proteção deve ser efetivada tanto pelo poder público, quanto por toda a coletividade.

Farias (1999, p. 285-286), citando José Afonso da Silva, frisa que a expressão Poder Público se refere a todas as entidades territoriais públicas. Leciona que os limites das competências em geral encontram-se previstas entre os artigos 21 e 32 da Constituição vigente, bem como que ela adotou uma construção complexa que suscita inúmeros conflitos.

Em matéria ambiental, tem-se ainda que a Constituição trouxe duas espécies de competência: competência administrativa ou material e competência legislativa. Enquanto a primeira se traduz na efetiva atuação dos entes federados a fim de executar tarefas ou praticar atos administrativos afetos ao poder de polícia; a segunda diz respeito à capacidade de editar leis e atos normativos referentes a matérias de interesse da coletividade.

A competência material se subdivide em exclusiva e comum. Aquela é modalidade de repartição horizontal de competência, por meio da qual reserva-se a realização da atividade a um único ente com exclusão dos demais. Essa forma de repartição de competência encontra-

\footnotetext{
${ }^{7}$ Art. 225. Todos têm direito ao meio ambiente ecologicamente equilibrado, bem de uso comum do povo e essencial à sadia qualidade de vida, impondo-se ao Poder Público e à coletividade o dever de defendê-lo e preservá- lo para as presentes e futuras gerações. (BRASIL, 1988).
} 
se prevista no artigo 21 , do texto constitucional $^{8}$ e são inerentes à União, uma vez que versam sobre matérias de interesse geral e encontram-se, a seu turno, precipuamente "relacionadas à exploração econômica dos recursos naturais com potencial energético" (RAMOS E SAMPAIO, 2015, p. 90).

A competência material comum, por sua vez, está inserida no artigo 23, do texto constitucional que, considerando a atuação do Poder Público como gestor do meio ambiente, bem como a natureza difusa do bem ambiental, conferiu a todos os entes federativos a incumbência de realizar atos voltados à sua proteção 9 .

Por vezes, a competência comum sujeita-se a diversos conflitos, uma vez que a forma em que foi estabelecida suscita dúvidas acerca de qual é a norma administrativa aplicável à situação. Nesse sentido, o parágrafo único do artigo 23 prevê que Lei Complementar fixará normas de cooperação entre os entes federativos, tendo em vista o equilíbrio do desenvolvimento e do bem-estar, regulamentação essa que adveio com a promulgação da Lei Complementar 140/11.

A segunda espécie de competência, qual seja, a competência legislativa, subdivide-se, a seu turno, em privativa, exclusiva, concorrente, supletiva e complementar. As competências privativas são aquelas próprias de um ente federativo, todavia, diferentemente das exclusivas, são passíveis de delegação. Encontram-se previstas nos artigos 22 e 30, da Constituição Federal, pertencendo, respectivamente, à União e aos Municípios, nos seguintes termos:

Art. 22. Compete privativamente à União legislar sobre:

IV - águas, energia [...];

XII - jazidas, minas, outros recursos minerais e metalurgia;

\footnotetext{
${ }^{8}$ Art. 21. Compete à União: [...] IX - elaborar e executar planos nacionais e regionais de ordenação do território e de desenvolvimento econômico e social; [...] XII - explorar, diretamente ou mediante autorização, concessão ou permissão: [...] a) os serviços e instalações de energia elétrica e o aproveitamento energético dos cursos de água, em articulação com os Estados onde se situam os potenciais hidroenergéticos; [...] XIX - instituir sistema nacional de gerenciamento de recursos hídricos e definir critérios de outorga de direitos de seu uso; XX instituir diretrizes para o desenvolvimento urbano, inclusive habitação, saneamento básico e transportes urbanos; [...] XXIII - explorar os serviços e instalações nucleares de qualquer natureza e exercer monopólio estatal sobre a pesquisa, a lavra, o enriquecimento e reprocessamento, a industrialização e o comércio de minérios nucleares e seus derivados [...]; XXV - estabelecer as áreas e as condições para o exercício da atividade de garimpagem, em forma associativa. (BRASIL, 1998).

${ }^{9}$ Art. 23 É competência comum da União, dos Estados, do Distrito Federal e dos Municípios: [...] III - proteger os documentos, as obras e outros bens de valor histórico, artístico e cultural, os monumentos, as paisagens naturais notáveis e os sítios arqueológicos; [...] VI - proteger o meio ambiente e combater a poluição em qualquer de suas formas; VII - preservar as florestas, a fauna e a flora; [...] Parágrafo único. Leis complementares fixarão normas para a cooperação entre a União e os Estados, o Distrito Federal e os Municípios, tendo em vista o equilíbrio do desenvolvimento e do bem-estar em âmbito nacional. (BRASIL, 1988).
} 
XVIII - sistema estatístico, sistema cartográfico e de geologia nacionais;

XXVI - atividades nucleares de qualquer natureza;

Parágrafo único. Lei complementar poderá autorizar os Estados a legislar sobre questões específicas das matérias relacionadas neste artigo.

Art. 30. Compete aos Municípios:

I - legislar sobre assuntos de interesse local; [...] (BRASIL, 1988).

A competência exclusiva, conforme supramencionado, também é própria de um ente federativo, todavia não é passível de delegação. Em relação a essa modalidade de competência legislativa, não há uma unanimidade por parte da doutrina. Alguns autores, tal como Silva (2005, p. 480), defendem que esta é a natureza da competência estadual prevista no artigo $25, \S 1^{\circ}$, da Constituição da República de $1988^{10}$, que se utiliza da técnica de atribuir a eles os poderes remanescentes (não atribuídos especificamente à União ou aos Municípios). Outros autores, tais como Farias (1999, p. 294) e Almeida (2007, p. 64) não realizam a diferenciação adotada entre as competências exclusivas e privativas, de forma que, a princípio, tais atribuições seriam indelegáveis, salvo disposição expressa em contrário do texto constitucional.

Em razão da dicção adotada pelo constituinte originário, que atribuiu as competências remanescentes reservadamente aos Estados-membros, filiou-se, na presente pesquisa, ao defendido por Silva (2005).

Na competência legislativa concorrente, tanto União, quanto Estados e Distrito Federal podem dispor sobre o assunto ou matéria, sendo que cabe à União editar normas gerais. É o que dispõe o artigo 24 a seguir transcrito:

Art. 24. Compete à União, aos Estados e ao Distrito Federal legislar concorrentemente sobre:

VI - florestas, caça, pesca, fauna, conservação da natureza, defesa do solo e dos recursos naturais, proteção do meio ambiente e controle da poluição;

VII - proteção ao patrimônio histórico, cultural, artístico, turístico e paisagístico;

VIII - responsabilidade por dano ao meio ambiente, ao consumidor, a bens e direitos de valor artístico, estético, histórico, turístico e paisagístico;

$\S 1^{\circ}$ No âmbito da legislação concorrente, a competência da União limitar-se-á a estabelecer normas gerais. [...] (BRASIL, 1988).

\footnotetext{
10 Art. 25. Os Estados organizam-se e regem-se pelas Constituições e leis que adotarem, observados os princípios desta Constituição. $\S 1^{\circ}$ São reservadas aos Estados as competências que não lhes sejam vedadas por esta Constituição [...] (BRASIL, 1988).
} 
Ramos e Sampaio (2015, p. 90) alertam que a exploração econômica de recursos naturais com potencial energético ou atividade de monopólio da União se submete à competência legislativa privativa deste ente. Isto ocorre porque esses bens a ela pertencem. No entanto, quando se fala em proteção dos recursos naturais, "a competência legislativa é concorrente, sendo atribuída a todos os entes federados".

Por fim, tem-se as competências supletivas e complementares. As supletivas dizem respeito à competência plena que adquirem os Estados e o Distrito Federal diante da inércia da União para editar normas gerais. Uma vez editada a norma geral, as normas regionais têm sua eficácia suspensa naquilo que forem contrárias à nova regulamentação. Os Municípios, por não se encontrarem abarcados pelo disposto no artigo 24 , $\S \S 3^{\circ}$ e $4^{\circ}$, da Lei Fundamental, não possuem competência legislativa supletiva. Ele possui, entretanto, competência legislativa complementar, de forma que, em conjunto com os Estados e Distrito Federal, consoante a previsão contida nos artigos $24, \S 2^{\circ}$ e 30 , II, do texto constitucional, podem, considerando a abrangência do interesse tutelado, complementar as normas mais abrangentes editadas pelos demais. ${ }^{11}$

\section{O PAPEL DO ENTE MUNICIPAL E OS LIMITES DE SUA COMPETÊNCIA}

Ao realizar uma construção histórica da origem e evolução dos Municípios, Hely Lopes Meirelles (2008, p. 33) leciona que ele teve seu surgimento como unidade políticoadministrativa na República Romana que, na tentativa de manter uma dominação pacífica sobre seus territórios conquistados, conferia a eles uma maior ou menor autonomia de acordo com a obediência de cada um para com as leis romanas impostas pelo Senado.

As municipalidades existem no Brasil, transplantadas pelo governo Português, desde a época colonial. Nesse período, entretanto, elas assumiram a mesma organização adotada pelos municípios Portugueses, regidos pelas Ordenações Afonsinas, Manuelinas e Filipinas adotadas pelo Brasil-colônia até a sua independência, não possuindo, portanto, qualquer autonomia em relação ao ente central.

\footnotetext{
${ }^{11}$ Art. 24. [...] § $2^{\circ}$ A competência da União para legislar sobre normas gerais não exclui a competência suplementar dos Estados. $\S 3^{\circ}$ Inexistindo lei federal sobre normas gerais, os Estados exercerão a competência legislativa plena, para atender a suas peculiaridades. $\S 4^{\circ}$ A superveniência de lei federal sobre normas gerais suspende a eficácia da lei estadual, no que lhe for contrário. (BRASIL, 1988)

Art. 30. Compete aos Municípios: [...] II - suplementar a legislação federal e a estadual no que couber; [...]. (BRASIL, 1988).
} 
As Constituições brasileiras promulgadas após o reconhecimento de sua independência continuaram a prever a existência das Municipalidades, conferindo a elas, de acordo com o momento histórico vivenciado, uma maior ou menor autonomia, ora limitandoas à categoria de corporações meramente administrativas, ora garantindo-lhes liberdades políticas e financeiras (MEIRELLES, 2008, p. 45). Todavia, foi somente com a Constituição vigente que elas passaram a ser reconhecidas como ente federativo de terceiro grau, hierarquicamente idêntico aos demais (União, Estados e Distrito Federal), dotados de capacidade de auto-organização, autogoverno, autoadministração e poder normativo próprio constitucionalmente reconhecido.

Assim, a Carta Constitucional de 1988 trouxe especial relevância ao ente municipal, relevância essa que deve ser considerada quando da interpretação das normas constitucionais de repartição de competências.

Consoante o supramencionado, os Municípios, no que tange à sua competência administrativa, encontra-se incumbido, juntamente com os demais entes federativos, de praticar atos destinados a proteger o meio ambiente. Ademais, no que diz respeito às suas competências legislativas, estão enquadrados tanto como detentores de competência privativa para legislar sobre matérias de interesse local, bem como possuem competência complementar, cabendo a ele, no âmbito de suas atribuições para legislar localmente, suprir lacunas deixadas pelas legislações estaduais e nacionais.

Tem-se, portanto, que ao estabelecer as competências municipais, o constituinte originário adotou uma técnica diferenciada, utilizando-se de uma expressão genérica "interesse local" - para designar as competências privativas desse ente. A ausência de definição delimitada acerca do vocábulo gera inúmeras discussões no que tange à sua abrangência.

Meirelles (2008), ao tentar conceituar o termo, enuncia que a expressão "interesse local" não invoca uma situação de exclusivo interesse municipal, posto que, caso o fizesse “[...] bem reduzido ficaria o âmbito da Administração local, aniquilando-se a autonomia de que faz praça a Constituição" (MEIRELLES, 2008, p. 111). O interesse local a que se refere o constituinte diz respeito, portanto, seguindo a regra geral adotada pelo teto constitucional, a matérias em que há predominância desse interesse.

Apesar de o texto constitucional não ter incluído o ente municipal dentre os detentores da competência legislativa concorrente contida no artigo 24 de seu texto, entende a doutrina 
ambientalista, majoritariamente, que ela se encontra implicitamente prevista no artigo 30, I, $\mathrm{CR} / 88$.

No mesmo sentido, ainda que não atribua expressamente ao ente municipal a competência para criar normas de proteção ambiental, tais matérias são inerentes ao âmbito do interesse local, posto que, consoante disserta Ferreira (2008, p. 73-74), "é no âmbito municipal que as pessoas são mais impactadas pelas necessidades diárias de proteção do seu meio ambiente, já que é nesse local que tais problemas se materializam mais nitidamente”.

Importante considerar, também, que para o exercício de atos relacionados à sua competência administrativa, o Município necessita, muitas vezes, de legislar acerca de matérias insuficientemente normatizadas pela União ou pelos Estados, principalmente quando considerado que a Administração Pública é regida pelo Princípio da Legalidade Administrativa, somente podendo praticar atos nos limites e na forma estabelecida pela lei. Esse também é o posicionamento defendido por Paulo de Bessa Antunes (2015):

[...] merece destaque o fato de que os Municípios não estão arrolados entre as pessoas jurídicas de direito público interno competentes para legislar sobre meio ambiente. No entanto, seria incorreto e insensato dizer-se que os Municípios não têm competência legislativa em matéria ambiental, visto que teriam que abrir mão de sua autonomia constitucional para cumprir os próprios mandamentos constitucionais de proteger o meio ambiente e combater a poluição. A aplicação pelos municípios dos complexos instrumentos normativos estaduais e municipais é sempre difícil e nem sempre atendem às necessidades locais, motivo pelos quais os Municípios acabam por estabelecer normas ambientais próprias, como a prática tem demonstrado. Por sua vez, o art. 30 da Constituição Federal atribui aos Municípios competência para legislar sobre: assuntos de interesse local; suplementar a legislação federal e estadual no que couber; promover adequado ordenamento territorial, mediante planejamento e controle do uso, do parcelamento e da ocupação do solo urbano; promover a proteção do patrimônio histórico-cultural local, observadas a legislação e a ação fiscalizadora federal e estadual. (ANTUNES, 2015, p. 74).

O próprio Estatuto das Cidades endossa tal entendimento. A Lei 10.257/01, editada para fins de regulamentação das competências municipais previstas no "caput" do artigo 182, da Constituição Federal ${ }^{12}$, previu, em seu artigo $2^{\mathbf{o}}$ :

Art. $2^{-}$A política urbana tem por objetivo ordenar o pleno desenvolvimento das funções sociais da cidade e da propriedade urbana, mediante as seguintes diretrizes gerais:

I - garantia do direito a cidades sustentáveis, entendido como o direito à terra urbana, à moradia, ao saneamento ambiental, à infra-estrutura urbana, ao transporte e aos serviços públicos, ao trabalho e ao lazer, para as presentes e futuras gerações;

\footnotetext{
${ }^{12}$ Art. 182. A política de desenvolvimento urbano, executada pelo Poder Público municipal, conforme diretrizes gerais fixadas em lei, tem por objetivo ordenar o pleno desenvolvimento das funções sociais da cidade e garantir o bem- estar de seus habitantes. [...] (BRASIL, 1988).
} 
IV - planejamento do desenvolvimento das cidades, da distribuição espacial da população e das atividades econômicas do Município e do território sob sua área de influência, de modo a evitar e corrigir as distorções do crescimento urbano e seus efeitos negativos sobre o meio ambiente;

VI - ordenação e controle do uso do solo, de forma a evitar:

g) a poluição e a degradação ambiental; [...]

h) a exposição da população a riscos de desastres.

VIII - adoção de padrões de produção e consumo de bens e serviços e de expansão urbana compatíveis com os limites da sustentabilidade ambiental, social e econômica do Município e do território sob sua área de influência;

XII - proteção, preservação e recuperação do meio ambiente natural e construído, do patrimônio cultural, histórico, artístico, paisagístico e arqueológico;

XIII - audiência do Poder Público municipal e da população interessada nos processos de implantação de empreendimentos ou atividades com efeitos potencialmente negativos sobre o meio ambiente natural ou construído, o conforto ou a segurança da população; [...] (BRASIL, 2001).

Da leitura do colacionado, percebe-se que o próprio legislador infraconstitucional reconheceu a importância do ente municipal como implementador de normas e instrumentos relacionados à proteção ambiental de seu território.

\section{A COMPETÊNCIA PARA LEGISLAR SOBRE DIREITO MINERÁRIO E SUA INTERSEÇÃO COM O DIREITO AMBIENTAL}

D’anna (apud SERRA, 2000, p. 28), conceitua o Direito Minerário como sendo "um conjunto de normas que estudam todo o relativo ao domínio das minas, a aquisição, conservação ou perda desse domínio, assim como as condições sob as quais é permitida a exploração e explotação, as relações entre o Estado e os particulares e destes entre si”.

A respeito dessas matérias não há dúvidas que elas são de competências legislativa privativa da União. Consoante o mencionado, o artigo 22, XII, do texto constitucional prevê uma competência privativa - e, portanto, delegável - da União para legislar sobre jazidas, minas, outros recursos minerais e metalurgia. Ademais, tal competência diz respeito não à proteção ambiental, mas a previsões relativas à exploração econômica desses recursos, uma vez que aquela se encontra enquadrada no âmbito das competências concorrentes, prevista no artigo 24, VI, da Constituição da República.

Apesar de haver na doutrina uma intensa discussão acerca da autonomia do Direito Minerário, não há dúvidas que esse ramo, autônomo ou não, está intrinsecamente ligado ao 
Direito Ambiental. Isso porque, segundo o defendido por Milaré (2014, p. 196), não há como extrair um mineral sem que haja dano ao meio ambiente. Acrescido a isso, o recurso natural minerário é um bem ambiental, de forma que é sim objeto de sua proteção (REMÉDIO JÚNIOR, 2013, p. 10).

Assim, apesar de o ente municipal não possuir competência para editar normas específicas acerca da exploração direta do bem mineral, é temerário afirmar, conforme fez o Relator, que o Município em nenhuma hipótese poderá legislar sobre mineração, estando sujeito a, caso o faça, ferir competência privativa constitucionalmente reservada à União. Isso porque, conforme visto, o Município possui competência para legislar sobre meio ambiente, de forma que se encontra autorizado a promulgar leis que interfiram diretamente na forma como é exercida a atividade minerária.

Ao exercê-la, entretanto, deverá observar o critério regente da repartição de competências constitucionais, qual seja, a predominância do interesse; bem como não extrapolar o interesse local. Serra (2000, p. 3) defende, ainda, que o Município não está autorizado a proibir abstratamente o exercício da mineração a fim de proteger o meio ambiente, que somente poderá ser considerada irreversivelmente prejudicial após a realização de meticuloso Estudo de Impacto Ambiental, e não poderá se dar, portanto, no âmbito de sua competência legislativa.

Em um caso semelhante, o Superior Tribunal de Justiça da província de Córdoba, na Argentina, decidiu que é sim possível que leis de âmbito estadual ou local prevejam disposições que restrinjam o exercício da atividade minerária, desde que não o faça de maneira a inviabilizar a prática extrativa, constitucionalmente resguardada, por completo. Assim, entendeu constitucional uma lei que, considerando as peculiaridades locais da província de Córdoba, conjugada com a existência de provas cabais de que existem técnicas alternativas à extração de minerais metálicos que não a mineração a céu aberto, e que esta última é extremamente prejudicial à paisagem e ao meio ambiente, proíbe o uso dessa técnica no território daquele Estado (CÓRDOBA, 2015).

Importante frisar, por fim, que o fato de o Município estar autorizado a legislar sobre matéria ambiental não o autoriza a extrapolar ou contrariar as legislações estaduais e nacionais editadas sobre o tema, sob pena de violar o pacto federativo. Dessa forma, conforme defendem Figueró e Colau (2014, p. 271) não é o simples fato de se estabelecer legislações ambientalmente mais protetivas que torna a norma constitucional, devendo, na análise de sua 
constitucionalidade, observar sempre a repartição de competências estabelecida pelo texto constitucional.

Apesar de recentemente o Supremo Tribunal Federal, em julgamento das ADIs 3.406 e 3.470 (BRASIL, 2017), ter adotado esse posicionamento, considerando constitucionais leis estaduais que, contrariamente à permissão concedida por lei federal, proibiram a exploração do amianto crisotila, por considerar que a tolerância da sua exploração e uso pela Lei 9.055/95 não poderia ser interpretada como obstáculo a uma atuação mais protetiva dos Estados e Municípios, bem como que diante da comprovação dos danos provocados pelo amianto à saúde a Lei Federal se traduz em uma proteção insuficiente, tal posicionamento é extremamente temerário, e, conforme defendido por Antunes (apud COLAU; FIGUERÓ, 2014, p. 271) não encontra qualquer amparo constitucional ou legal, criando diversas antinomias cujo estudo não constitui o objeto desse trabalho.

\section{CONCLUSÃO}

Concluiu-se, portanto, que a atividade extrativa mineral é de suma importância para a economia nacional, sendo responsável por quase 5\% do Produto Interno Bruto (PIB) brasileiro. Nesse cenário, Minas Gerais está em posição de destaque, uma vez que é um estado de tradição mineira, localizado geograficamente em um território rico em minerais e, portanto, assume a liderança na extração de vários dos minérios de maior relevância para o Brasil destinados a comercialização no mercado externo.

Contudo, considerando-se os impactos negativos inerentes à atividade, é imprescindível que o Estado edite normas para o seu controle, a fim de promover um desenvolvimento sustentável da atividade.

O Município de Lagoa Santa é um excelente exemplo da necessidade de tal proteção. Esse ente periférico, apesar de ter encontrado na extração mineral de calcita e calcário uma das principais fontes para o suporte dos cofres municipais, está, em razão de suas riquezas naturais e culturais, resguardado por uma área de proteção ambiental (APA) denominada Carste Lagoa Santa, instituída justamente com vistas a garantir uma compatibilização da exploração mineral com a garantia de um meio ambiente ecologicamente equilibrado na região. Assim, a adequada delimitação das competências municipais para estabelecer regras de direito minerário é imprescindível para essa municipalidade. 
Nesse sentido, verificou-se que a Constituição de 1988 adotou um modelo de federalismo inovador, classificado como cooperativo e de integração, com três esferas de poder, tendo essa forma de organização do Estado um impacto direto na forma como o constituinte atribui competências.

Dessa maneira, a Constituição da República de 1988 adotou um complexo modelo de repartição das atribuições incumbidas originariamente ao governo central para cada um de seus entes federativos, distribuindo-as horizontalmente, adotando as técnicas de enumeração das competências a serem assumidas por cada esfera governamental de forma exclusiva ou privativa, ou verticalmente, quando as distribui atribuindo áreas comuns de atuação entre os entes federativos (comuns, concorrentes, supletivas e complementares). Ademais, estabeleceu como critério de referência para tal repartição o princípio da predominância do interesse.

Nessa sistemática, percebe-se que foi conferida especial importância ao ente municipal, posto que se reconheceu sua capacidade de, por se encontrar mais próximo do problema, estabelecer normas mais eficientes para a solução de violações de âmbito local, principalmente em matéria de meio ambiente.

No caso das competências legislativas sobre Direito Minerário, destinou-se privativamente à União a incumbência de estabelecer normas sobre jazidas, minas e outros recursos minerais, estando esse poder diretamente relacionado à regulamentação das atividades que exploram economicamente recursos com potencial energético. Paralelo a isso, o constituinte, visando ampliar a proteção ao meio ambiente consagrada no artigo 225, do texto constitucional, impôs a todos os entes federativos a obrigação de legislar, bem como promover atos destinados ao resguardo do meio ambiente ecologicamente equilibrado. Nessa seara, a competência das municipalidades ficou reservada a assuntos relacionados ao seu setor de atuação, qual seja, matérias que envolvem interesses predominantemente locais.

Por fim, atestou-se que o Direito Ambiental interfere de forma direta na esfera do Direito Minerário, posto que, além de os recursos minerais serem considerados um bem ambiental, a sua extração gera, inegavelmente, expressivos impactos ambientais. Portanto, constatou-se que, no exercício de sua competência legislativa, o Município pode promulgar atos que interfiram diretamente no exercício da atividade extrativa mineral, sem, entretanto, inviabilizá-la abstratamente, visto que, para se ter certeza se os danos gerados pela atividade são maiores que seus benefícios se faz necessária a realização de estudos de impacto, que somente serão infirmados quando do licenciamento do empreendimento minerário. 
Isso posto, conclui-se que, no caso ora analisado, agiram corretamente os julgadores da Ação Direta De Inconstitucionalidade $n^{\circ}$ 1.0000.15.088096-1/000 ao entenderem pela inconstitucionalidade do ato normativo impugnado. O Município de Lagoa Santa, ao promulgar lei que proibia o exercício da atividade minerária em seu território extrapolou as competências municipais, inviabilizando a prática de uma atividade econômica não só autorizada, mas fomentada pelas Constituições Federais e Estadual, bem como essencial para a economia municipal. Todavia, apesar de o ente municipal não possuir competência para editar normas específicas acerca da exploração direta do bem mineral, equivocada foi a afirmação da relatoria da presente ação, ao dizer que as municipalidades não estariam autorizadas em nenhuma hipótese a legislar sobre mineração, sob pena de ferir não só o pacto federativo, mas também fragilizar de forma flagrante a proteção ambiental ampla prevista pela Constituição da República de 1988.

\section{REFERÊNCIAS}

ALMEIDA, Fernanda Dias Menezes de. Competências na Constituição de 1988. 4. Ed. São Paulo: Atlas, 2007.

ANTUNES, Paulo de Bessa. Federalismo e competências ambientais. 2. ed. Rio de Janeiro: Atlas, 2015.

ATAÍDE, Pedro. Direito Minerário. Salvador: JusPodivm, 2017.

BRASIL. Constituição (1891). Constituição da República dos Estados Unidos do Brasil, de 24 de fevereiro de 1891. Disponível em: <http://www.planalto.gov.br/ccivil_03/constituicao/constituicao91.htm>. Acesso em: 01 mai. 2018.

BRASIL Constituição (1988). Constituição da República Federativa do Brasil de 1988. Brasília: Senado Federal, Centro Gráfico, 1988.

BRASIL. Decreto n. 1, de 15 de novembro de 1889. Proclama provisoriamente e decreta como forma de governo da Nação Brasileira a República Federativa, e estabelece as normas pelas quais se devem reger os Estados Federais. Disponível em: <http://www.planalto.gov.br/ccivil_03/decreto/1851-1899/d0001.htm>. Acesso em: 01 mai. 2018.

BRASIL. Decreto n. 98.881, de 25 de janeiro de 1990. Dispõe sobre a criação de área de proteção ambiental no Estado de Minas Gerais e dá outras providências. Disponível em: <http://www.planalto.gov.br/ccivil_03/decreto/1990-1994/D98881.htm>. Acesso em: 01 mai. 2018. 
BRASIL. Departamento Nacional de Produção Mineral. Anuário Mineral Brasileiro: Principais substâncias metálicas. Brasília: DNPM, 2016.

BRASIL. Lei Complementar 140, de 08 de dezembro de 2011. Disponível em: <http://www.planalto.gov.br/ccivil_03/leis/lcp/lcp140.htm>. Acesso em: 01 mai. 2018.

BRASIL. Lei n. 10.257, de 10 de julho de 2001. Regulamenta os arts. 182 e 183 da Constituição Federal, estabelece diretrizes gerais da política urbana e dá outras providências. Disponível em: <http://www.planalto.gov.br/Ccivil_03/leis/LEIS_2001/L10257.htm>. Acesso em: 01 mai. 2018.

BRASIL. Lei n. 10.406, de 10 de janeiro de 2002. Institui o Código Civil. Disponível em: <http://www.planalto.gov.br/ccivil_03/Leis/2002/110406.htm>. Acesso em 10 jun. 2018.

BRASIL. Supremo Tribunal Federal. Informativo n. 886, de 27 de novembro a $1^{\circ}$ de dezembro de 2017. Contém resumos não-oficiais de decisões proferidas pelo Tribunal. Disponível em: <http://www.stf.jus.br/arquivo/informativo/documento/informativo886.htm>. Acesso em: 01 mai. 2018.

CABRAL JÚNIOR, Marsis; et al. A mineração no Estado de São Paulo: situação atual, perspectivas e desafios para o aproveitamento dos recursos minerais. Geociências, São Paulo, v. 27, n. 2, p. 171-192, 2008.

COLAU, Suzane Girondi; FIGUERÓ, Fabiana da Silva. Competência legislativa ambiental e aplicação da norma mais restritiva como forma de resolução de conflitos: uma análise crítica. Veredas do Direito, Belo Horizonte, v. 11, n. 21, p. 255-280, jan/jun 2014.

CÓRDOBA. Superior Tribunal de Justiça. Expediente no 1798036, de 11 de agosto de 2015. Disponível em: <http://www.fundeps.org/wp-content/uploads/2017/06/cemincor_y_otra_c_superior_gobierno_de_la_provincia_-_accion_declarativa_de_inconstitucionalidad-1.pdf $>$. Acesso em 12 jun. 0218.

COSTA, Beatriz Souza. Meio Ambiente como direito à vida: Brasil, Portugal e Espanha. 3. ed. Rio de Janeiro: Lumen Juris, 2016.

ENRÍQUEZ, Maria Amélia R. da S. Maldição ou dádiva? Os dilemas do desenvolvimento sustentável a partir de uma base mineira. Brasília, 2007. 449 f (Tese).

FABRIZ, Daury Cesar. Federalismo, municipalismo e direitos humanos. Revista do Tribunal de Contas do Estado de Minas Gerais, v. 77, n. 4, p. 76-95, out./dez. 2010. Disponível em: <revista1.tce.mg.gov.br/Content/Upload/Materia/1085.pdf>. Acesso em: 11 jun. 2018.

FARIAS, Paulo José Leite. Competência federativa e proteção ambiental. Porto Alegre: Sergio Antônio Fabris, 1999.

FEIGELSON, Bruno. Curso de Direito Minerário. São Paulo: Saraiva, 2012. 
FERREIRA, Willia de Cássia Soares. Competência municipal para legislar sobre o meio ambiente: o interesse local como parâmetro à competência legislativa dos municípios. Belo Horizonte, 2018. $111 \mathrm{f}$ (Dissertação).

FLEISCHER, David Ivan Rezende. São Thomé das Letras e Lagoa Santa: mineração, turismo e risco ao patrimônio histórico e natural. Cadernos do Campo, São Paulo, n. 14/15, p. 1-382, 2006.

INSTITUTO BRASILEIRO DE MINERAÇÃO. Panorama da Mineração em Minas Gerais. Brasília: IBRAM, 2015.

MEIRELLES, Hely Lopes. Direito Municipal Brasileiro. 16. ed. atual. São Paulo: Malheiros, 2008.

MILARÉ, Édis. Direito do ambiente. 9. ed. rev., atual. e ampl. São Paulo: Editora Revista dos Tribunais, 2014.

MINAS GERAIS. Tribunal de Justiça do Estado de Minas Gerais. Ação Direta de Inconstitucionalidade $\mathrm{n}^{\mathrm{o}}$ 1.0000.15.088096-1/000. Relator: Desembargador Moreira Diniz. Diário de Justiça Eletrônico, 23 de setembro de 2016.

MORAES, Alexandre de. Federação brasileira: necessidade de fortalecimento das competências dos estados-membros. Revista de Direito Administrativo, Rio de Janeiro, v. 251, p. 11-27, mai. 2009. Disponível em: <http://bibliotecadigital.fgv.br/ojs/index.php/rda/article/view/7526/6020>. Acesso em: 10 jun. 2018.

RAMOS, Vinicius Diniz e Almeida; SAMPAIO, José Adércio Leite. Conflito de competência administrativa em matéria ambiental: primazia dos interesses da União ou ofensa ao Pacto Federativo? Revista Direito Ambiental e Sociedade, v. 5, n.2, p. 82-109, 2015.

REMÉDIO JÚNIOR, José Ângelo. Direito Ambiental Minerário: mineração juridicamente sustentável. Rio de Janeiro: Lumen Juris, 2013.

SERRA, Helena Silvia. A formação, os condicionamentos e a extinção dos direitos minerários. Campinas, SP, 2000 (Tese).

SILVA, José Afonso da. Curso de Direito Constitucional Positivo. 25. ed. rev., atual. São Paulo: Malheiros, 2005.

\section{DADOS DA PUBLICAÇÃO}

Categoria: artigo submetido ao double-blind review.

Recebido em: 13/06/2018.

Aceito em: 02/09/2019. 
MENDES, Gabriela Ariane Ribeiro; COSTA, Beatriz Souza. A competência municipal para legislar sobre Direito Minerário e a possibilidade de proibição do exercício da atividade extrativa. Revista da Faculdade de 